\title{
ESTUDIOS
}

\section{Pablo Neruda: el Sistema del Poeta}

\begin{abstract}
Yo cambié tantas veces de sol y de arte poética que aún estaba sirviendo de ejemplo en cuadernos de [melancolía cuando ya me inscribieron en los nuevos catálogos de los [optimistas, y apenas me babian declarado oscuro como boca de lobo

[o de perro denunciaron a la policia la simplicidad de mi canto y más de uno encontró profesión y salió a combatir mi [desino en chileno, en francés, en inglés, en veneno, en ladrido, [en susurro.
\end{abstract} La barcarola (1967)

Como Goethe, Neruda parece haber sufrido más de una metamorfosis, en su ya larga carrera; parece haber dejado abandonada para siempre la piel juvenil de sturmer; haber renegado definitivamente de su melanco. lía y su desorden, y haber asumido un clasicismo que (mutatis mutandis) recuerda al del otoñal Apolo de Weimar. Ahora que se acerca a los setenta, Neruda puede mirar hacia atrás y descubrir, en los cada vez más gruesos volúmenes de sus Obras Completas, en los premios que no cesan de coronarlo de laureles, en la multiplicación incesante de sus libros, viejos y nuevos, esa imagen definitiva del poeta, tel qu'en lui même en fin l'éternité le change. Es esa mirada retrospectiva, la que Pablo Neruda empieza a echar ya en el Canto General (1950) y que se acentúa en las Memorias de $O$ Cruzeiro (1962), para culminar en el vasto Memorial de Isla Negra (1964), con que el poeta mismo celebra sus sesenta años. En esa mirada, él registra sus cambios de piel, define sus crisis, glosa los ya numerosos avatares. Un Neruda cambiante y sucesivo, una imagen 
que no cesa de alterarse, una sucesión de personate poéticas. La mirada retrospectiva registra el cambio.

Pero también certifica la permanencia.

Porque la paradoja de estas mudas de piel, de esta incesante metamorfosis, es que el poeta cambia para seguir siendo el mismo. Los cambios (como he tratado de mostrar en la parte biográfica de El viajero inmóvil), ${ }^{x}$ tiene un sentido unívoco: permitir al poeta desarrollarse a lo largo de una obra y de una vida de constante exigencia creadora; sostener al poeta en su movimiento central sin paralizar la posibilidad de la aven. tura. Por eso, Neruda (como Goethe) cambia sin descaracterizarse, asume nuevas máicaras para expresar mejor la persona única, huye para quedarse siempre clarado en su mismo centro.

Pero si se deja de lado la peripecia biográfica y se atiene uno solamente a los textos del poeta, también es posible ver en su sucesión contradictoria, en la muda de piel de su estética, el mismo fenómeno de cambio e inmovilidad, de aventura y orden.

De los muchos enfoques posibles de este tema quisiera hoy elegir uno que me parece contribuye a aclarar completamente el proceso. Es el que consiste en el análisis de una estética explícita en la obra de $\mathrm{Ne}$ ruda. Y digo explícita porque todo poeta tiene su estética aunque no se cuide de expresarla explícitamente, e incluso aunque (como M. Jourdain con la prosa) la tenga sin saberlo. No. En el caso de Neruda no es así. En muchos momentos de su obra el poeta ha expresado, muy explícita y deliberadamente, cuál es su Arte Poética. Esas declaraciones asumen, a veces, la forma de un poema, en la mejor tradición horaciana. Otras veces, son textos en prosa, artículos críticos, hasta declaraciones periodísticas. Pero en estos textos, a través de ellos, es posible recomponer una estética explicita y hasta programática de Pablo Neruda.

Subrayo una vez más el adjetivo explicita porque existe desde hace tiempo el prejuicio de que Neruda es un poeta volcánico y torrencial, intuitivo, desconocedor de las reglas del arte. Incluso circulan por ahí trabajos de quienes le cuentan las sílabas, o le corrigen la puntuación, o le prosifican los versos para que queden más claros. Todo eso está bien, si se acepta como la inevitable labor pedagógica de la crítica, la puesta en limpio de un texto complejo, para hacerlo más accesible al lector no especializado. Pero estos derechos de la crítica no nos deben hacer olvidar los derechos de la poesía. $Y$ menos aún nos deben hacer olvidar

1 Emir Rodríguez Monegal: El viajero inmóvil. Introducción a Pablo Neruda. (Buenos Aires, Editorial Losada, 1966). En el curso de este trabajo será citado como El viajero. 
que el poeta (sí, este mismo poeta volcánico y torrencial) sabe más de lo que parece, conoce muy lúcidamente su oficio, tiene una poética, o varias.

El volcán, el torrente, también tiene'n sus leyes, su sistema.

De manera que una exploración, asi sea preliminar como la que po. dré efectuar ahora, de la estética de Pablo Neruda puede ayudar a situar lo que he llamado el sistema del poeta. Es decir: el conjunto de reglas, - principios, que rige muy explícitamente su poesía. Para llegar a definir ese sistema, esa estética, me apoyaré en textos de distintas épocas y distintos orígenes. Algunos son muy conocidos, y han sido harto glosados por la crítica; otros lo son menos, pero merecen ser más difundidos. En todos, la preocupación del poeta por definir su poesía (y por definirse) alcanza las condiciones básicas de lucidez e intuición que gatantizan el acceso al sistema completo.

El primer texto que invoco ahora es el poema que se titula, muy explicitamente, "Arte poética", y figura en la primera parte de Residencia en la tierra (1933). Ya Amado Alonso le ha dedicado algunas páginas de su admirable y discutible estudio: Poesia y estilo de Pablo Ne. ruda (1940). Otros críticos, en particular Alfredo Lozada, han comentado y ampliado las observaciones de Alonso. ${ }^{2}$ Aquí me propongo examinar el poema desde un ángulo algo distinto. Dice así:

Entre sombra y espacio, entre guarniciones y doncellas, dotado de corazón singular y sueños funestos, precipitadamente pálido, marchito en la frente y con luto de viudo furioso por cada día de vida, ay, para cada agua invisible que bebo soñolientamente y de todo sonido que acojo temblando, tengo la misma sed ausente y la misma fiebre fría un oído que nace, una angustia indirecta, como si llegaran ladrones o fantasmas, y en una cáscara de extensión fija y profunda,

2 Amado Alonso: Poesía y estilo de Pablo Neruda. Interpretación de una poesia hermética (Buenos Aires, Editorial Losada, 1940). Hay segunda edición ampliada (Buenos Aires, Editorial Sudamericana, 1951). Las citas, salvo indicación en sentido contrario, se hacen por la primera edición. El trabajo de Alfredo Lozada se titula, "Estilo y poesía de Pablo Neruda: Examen de la interpretación de Amado Alonso de Residencia en la tierra", in PMLA, vol. LXXIX, No. 5 (New York, December 1964, pp. 648-663). 
como un camarero humillado, como una campana un poco ronca, como un espejo viejo, como un olor de casa sola en la que los huéspedes entran de noche perdidamente ebrios, y hay un olor de ropa tirada al suelo, y una ausencia de flores -posiblemente de otro modo aún menos melancólicopero, la verdad, de pronto, el viento que azota mi pecho, las noches de substancia infinita caídas en $\mathrm{mi}$ dormitorio, el ruido de un día que arde con sacrificio me piden lo profético que hay en mí, con melancolia y un golpe de objetos que llaman sin ser respondidos hay, y un movimiento sin tregua, y un nombre confuso. ${ }^{3}$

En cuatro lugares distintos de su libro ha examinado Alonso con algún detalle el poema. La primera vez es para indicar su tema general:

Hay en este poema unos bastidores de sombra y espacio, de sueños funestos, frente pálida y marchita, campana ronca, espejo viejo, olor de casa sola; y en este escenario, la sed de agua invisible. El anhelo, que lleva en sí esperanza y promesa de logro: goce de amar y goce de poetizar: (...)

La angustia le asalta, pero es una angustia indirecta, como si se sintiera temeroso de ladrones o fantasmas. Su poesía es el viento repentino que le azota el pecho y le pide lo profético que hay en él. El acento se pone en esta afirmación y exaltación de sí mismo y de su chispa sagrada. Por eso la atmósfera es de melancolía, no de congoja, en este golpe de objetos que llaman sin respuesta. (24)

El resumen parece adecuado y no deja de señalar ninguno de los aspectos básicos del poema. Pero es un resumen, o glosa, de su tema y su punto de vista, únicamente. Unas páginas más adelante, en el capítulo II, titulado "Intuición y sentimiento", intenta Alonso un análisis más pormenorizado de la estructura de imágenes del poema. Empieza con una nueva síntesis que es, pedagógicamente, muy acertada:

El poema, que consta de una tirada única de 21 versos, expresa en los 15 primeros el ácido gusto de boca que le deja la vida (1-14, autorretrato con cuatro rasgos característicos; 5-9, anhelos de romper el círculo angustioso de su soledad; 10.15, como respuesta a

3 Todos los textos de Neruda se citan por la tercera edición de sus Obras Completas (Buenos Aires, Editorial Losada, 1968, 2 vols.), salvo indicación en sentído contrario. En el curso de este trabajo esta edición será indicada como $O . C_{\text {๙ }}$ $y$ el numeral romano del tomo correspondiente. 
esos anhelos y a su dolorosa sensibilidad, contemplación de la inevitable degradación de su propio ser); en los 6 versos últimos, la gloriosa compensación del don poético y de su ejercicio. (...)

El objeto contemplado es su propia persona en medio de la vida y el mundo. La intuición, mucho más honda que la mera percep. ción inteligente, busca y configura el sentido último del objeto. Y el sentido configurado por la intuición del poeta debe ser la ex. presión justa del sentimiento con que el poeta se ve a sí mismo en la perpetua desintegración y degradación en que consiste la vida le conjura imágenes de cosas desgastadas, quebradas, envejecidas, ensuciadas, envilecidas, sórdidas, tocadas de la ruina. No cosas de por sí sin valor, sino cosas cuyo valor está en caducidad. (30.31)

A continuación, Alonso analiza con algún detenimiento ciertas imágenes de los versos 5-15. En otro pasaje de su libro (pp. 52-57) vuelve sobre la primera parte del poema, hasta ese verso 15 que sirve de puente, o bisagra, entre las dos partes. El crítico español descifra imágenes, prosifica y descodifica esta poesía que a él le parece singularmente hermética (como lo indica el subtítulo de su libro) y singularmente negativa. Ya veremos hasta qué punto es posible admitir estos términos. La última referencia extenisa a este poema ocurre en el capítulo VI, "La forma". Allí Alonso dedica un párrafo largo a comentar precisamente los seis últimos versos, aquéllos que había pasado por alto en el análisis detallado del capítulo II. Dice entonces:

Es una concepción neorromántica de la inspiración, que guarda de la romántica la actitud receptiva y profética del inspirado, pero que en lugar del misterioso ente inspirador, espíritu universal que insuflaba en el inspirado un sentido, una forma de la realidad, ahora pone a la realidad misma en su realísimo desorden, en su movimiento sin tregua, pidiendo lo profético que hay en el poeta, llamándolo sin más respuesta que un nombre confuso. El nombre confuso, lo informe del poema, tiene que expresar simbólicamente lo informe de la realidad. (134)

De inmediato, Alonso trata de situar esta forma de poetizar de Neruda en el contexto de la poesía contemporánea:

En esta desestima de la forma y en este concepto de la inspiración poética parecen haber influido las fugaces escuelas de los futuristas y superrealistas franceses (Blaise Cendrars, Louis Aragon, etc.), 
cuyo programa era dejar que se cumplan las asociaciones psíquicas sin entrometerse el poeta con propósitos de forma, dejarse invadir por el caótico espiritu universal y obedecerle poéticamente, sin colaborar con él más que con "cierta orientación al poema", como si la misión de la poesía fuera no tanto ia creación de mundos de sentimiento y fantasía cuanto el sentir una presencia oculta de algo misterioso y extraño al mundo práctico de nuestra inteligencia: es el sentido que tiene ese "golpe de objetos que llaman sin ser res. pondidos".

Los superrealistas franceses se desbandaron pronto, y en los diez años de poesía recogidos en Residencia, Pablo Neruda ha ido aban. donando la pura aventura a la deriva, para dar cada vez más lugar a sus fuerzas poéticas creadoras y a lo que en la poesia hay de forma.' (134-135)

Es posible estar de acuerdo con Alonso en la interpretación general de este poema, en particular con lo que él observa en la página $24 \mathrm{y}$ completa con el análisis de imágenes de las páginas 30-31. Aunque hay en esta parte de su escolio algún error (en la p. 32 hasta cita mal el verso 15), la caracterización de este aspecto del poema es acertada. ${ }^{4}$ Alon. so ve bien sobre todo dos cosas importantes: (a) el objeto del poema es el poeta; (b) la poesía es una compensación ante un mundo que se desintegra. También describe acertadamente el origen romántico de la inspiración del poeta (p. 134) y el carácter predominantemente negativo de esta etapa de la producción poética de Neruda. Pero hay otras cosas en su análisis que son muy discutibles, o que implican una incomprensión muy grave no sólo de aspectos básicos de la poesía de Neruda sino de toda la poesía contemporánea. En primer lugar, examinemos ciertas omisiones en lo que se refiere al carácter negativo de esta poesía. El verso 15 dice explícitamente:

--posiblemente de otro modo aún menos melancólico-,

Subrayo el ain menos porque Alonso omite hacerlo. Sin embargo, la importancia de esta matización dentro del tono negro del poema no puede ser pasada por alto. A partir de este verso, el poema se vuelve sobre sí mismo y cambia completamente el sistema de imágenes. La visión negra de los primeros catorce versos que la palabra melancólico había situado tan precisamente ("melancolía" es bilis negra, en la etimología más

4 El error de Alonso se repite en la segunda edición, p. 36. 
aceptada) resulta ahora transformada. ${ }^{5}$ El poeta da lugar a toda una serie de imágenes cuya raíz afectiva no es la angustia, ni la desesperación, ni la melancolía. Por el contrario, un sentimiento de unidad oscura con el cosmos se apodera de él. Aunque Alonso ve bien un aspecto de la transformación -en la página 24 indica que "el acento se pone en esta afirmación y exaltación de sí mismo y de su chispa sagrada" -, sin embargo no ve del todo bien la metamorfosis que se ha producido en los últimos seis versos y sigue insistiendo: "Por eso la atmósfera es de melancolía, no de congoja, en este golpe de objetos que llaman sin respuesta".

El error consiste en creer que la melancolía de los primeros catorce versos sobrevive al descubrimiento de la vocación profética en los últimos seis. Alonso registra, en la página 24, la presencia del "viento repentino que le azota el pecho y le pide lo profético que hay en él". Pero no registra, ni analiza, las otras imágenes que acompañan a ese viento. Es decir: anota el viento, viento de origen romántico, victorhuguesco y apasionado, pero no comenta para nada las noches de substancia infinita, también de clara estirpe romántica; ni registra ese día que arde con sacrificio (qué palabras clave: arder, sacrificio). Y por eso, la llamada de lo profético que hay en el poeta queda reducida para Alonso a la inspiración. En una nota a las páginas 30-31, en que hace la prosificación del poema, los versos 15.21 se condensan en este telegrama:

...pero de pronto, la inspiración me llama y en el poetizar encuentro el confuso sentido que me niega la vida. (31)

El don profético es algo más que la inspiración. Los seis versos finales del poema sintetizan una estética de la poesía como profecía, de la poesía como algo que está surgiendo del fondo más abismal del mundo y del poeta, de la poesía como iluminación, como rito y como salvación. De todas estas notas, Alonso sólo reconoce la inspiración y la salvación. Se le escapa precisamente lo más significativo: la apelación a lo profético. ${ }^{6}$

Lo curioso es que Alonso había encontrado, en las páginas 134-135,

5 Para la etimología de la palabra melancolía, véase Joan Corominas: Breve diccionario etimológico de la lengua castellana (Madrid, Editorial Gredos, 1967, 2a. edición), p. 389.

6 En su extenso estudio, "Interpretación de Residencia en la tierra de Pablo Neruda" (Mapocbo, Año I, tomo I, Santiago de Chile, julio, 1963, p. 9), Jaime Concha subraya también lo "profético" del poema "Arte poética" y lo vincula con otro verso de "Colección nocturna", del mismo libro. Pero su interpretación se detiene en esta aproximación y sigue otros rumbos. 
la exacta filiación estética de Neruda. Allí indica su vinculación con el romanticismo y con el superrealismo. Pero si se repasa su caracterización de este aspecto de la poesía de Neruda, se podrá ver por qué Alonso se equivoca, y tan gravemente. Su síntesis de la raíz romántica de la poesía de Neruda refleja una concepción simplista de la inspiración como un "misterioso ente inspirador". Y opone a ese misterioso ente la "realidad". Pero en la poesía romántica de más profunda inspiración (pienso en Blake, en Hugo, en Hölderlin, en Nerval) las cosas no ocurren así. Como tampoco ocurren así en Neruda. No hay un "espíritu universal", separado y opuesto a la realidad: hay la realidad, en todas sus dimensiones. Y la operación que habrá de realizar Neruda (sobre todo en Residiencia en la tierra) es dar voz a esa realidad total, en sus contradicciones, angustias, confusiones, melancolías, pero también en sus golpes de misterio, de profecía, de plenitud.

De la misma manera se equivoca Alonso al hablar del superrealismo. En primer lugar, se confunde al citar juntos el futurismo (movimiento efímero aunque interesante) y el superrealismo, movimiento que lejos de ser fugaz, y de haberse desbandado, como dice Alonso en 1940, ha continuado existiendo, evolucionando e impregnando la poesía y el arte de este siglo. Del vasto y complejo superrealismo, Alonso sólo cita a Cendrars y a Aragon, aunque incluye en una nota una cita del primer Manifiesto del Superrealismo, de André Breton (1924). La perspectiva, aún en 1940, es totalmente insuficiente. También erra Alonso al ver la escritura automática como el centro de las pesquisas superrealistas. Una lectura atenta del Manifiesto, le hubiera permitido ver que se trataba de una revolución completa en la manera de aprehender $l_{a}$ realidad. $Y$ que no perseguía una ausencia de forma sino la búsqueda de formas que permitan un acceso total a la realidad. La última cosa importante que se le escapa a Alonso es la relación entre lo que él llama el neorromanticismo de Neruda y el superrealismo. Breton y los suyos no sólo proclamaron una poesía nueva y moderna. También reivindicaron al romanticismo, y en particular algunos de sus genios más soslayados, como Blake, el Marqués de Sade, Lautréamont. Si Alonso hubiera entendido mejor a qué clase de romanticismo profético estaba vinculado Neruda; si hubiera visto más hondamente sus conexiones (simpatías y diferencias, en realidad) con el superrealismo, entonces su análisis de "Arte poética" no habría sufrido de tantos errores y omisiones. ${ }^{7}$

7 Para una lectura verdaderamente iluminadora de este periodo de la poesía de los siglos $\mathrm{xIx}$ y $\mathrm{xx}$, véase Octavio Paz: El arco y la liva (México: Fondo de Cultura Económica, 1967, segunda edición), especialmente las pp. 74-97. 
La poesía que Neruda propone en su "Arte poética" es, pues, una poesía profética. No una poesía sólo hermética, como cree Alonso. La confusión, el caos, la oscuridad, la melancolía; sí, todo eso existe y está allí. Pero también hay algo más. Hay una metamorfosis del poeta y del mundo que empieza en el verso 15 y que permite a Neruda ver en lo oscuro, encontrar su camino confuso a través del don de la profecía. El error de Alonso puede explicarse, tal vez, por su propia formación poética. Alonso llega a Neruda por el camino de Góngora y de la lectura de Góngora que hicieron en España los poetas de la generación del 27.8 Aunque en muchos aspectos, la poesía de Góngora ha dejado su huella en la de Neruda, el poeta chileno es de otra estirpe que su maestro cordobés. Su filiación está, como ya he indicado, en ese tipo de poeta profético que fue William Blake a fines del siglo dieciocho y comienzos del diecinueve, que fue Victor Hugo en buenas parte de su vastísima obra, que fue Lautréamont en los Chants de Maldoror, que fue Walt Whitman en sus Leaves of Grass. La multiplicidad y complejidad y oscuridad del mundo se expresa pata ellos, como para Neruda, a través del trance profético. El poeta es, en esta concepción, el espacio donde el viento y la noche y el día que arde se encuentran para suscitar por medio de la palabra el don profético. Desde el mismo vortex de esta conflagración de elementos y sustancias, centrado en la oscuridad y el movimiento, el poeta habla. Ahí está la raíz del canto.

Es posible llegar a esta conclusión por otro camino. En testimonios que sólo se han conocido muy posteriormente al libro de Alonso y que, por lo tanto, éste no pudo haber utilizado, Pablo Neruda ha confirmado esta visión profética de su poesía. Me refiero, es claro, a las cartas que envió el poeta a José Santos González Vera, el fino humorista chileno, y a Héctor A. Eandi, escritor argentino con quien mantuvo una larga amis $x d$ epistolar. Estas cartas pertenecen a finales de la década del veinte y ya han sido glosadas in extenso, en mi libro sobre Neruda. ${ }^{9}$

Aquí sólo recogeté algunos fragmentos que ayudan a explicitar ese sentido de lo profético que impregna toda la poesía de Neruda en esos

8 Una lectura muy distinta de Góngora es la que propone José Lezama Lima en "Sierpe de don Luis de Góngora", in Analecta del reloj (La Habana, Orígenes, 1953).

9 Todo este petíodo de la vida literaria de Neruda está estudiado en las pp. 55-75 de El viajero. Véase también las pp. 208-212. 
años. No se olvide que el poeta está viviendo entonces en el Oriente, rodeado por gentes que hablan lenguas que él desconoce por completo, obligado a usar el inglés (idioma que hasta el día de hoy habla mal) como único vínculo con la minoría educada a la europea. Son años que yo he comparado con una temporada en el infierno; años en que la única persona con la que Neruda puede hablar de poesía es su amigo inglés, Andrew Boyd, que le presta los poemas de Blake y los de T. S. Eliot, las novelas de D. H. Lawrence y de Aldous Huxley.

La primera carta a Eandi en que Neruda define sus aspiraciones poéticas, sus vacilaciones, su crisis, es de mayo 11, 1928. Allí dice:

A veces por largo tiempo estoy aquí tan vacío, sin poder expresar nada ni verificar nada en mi interior, y una violenta disposición poética que no deja de existir en mí, me va dando cada vez una vía más accesible, de modo que mi labor se cumple con suftimiento, por la necesidad de ocupar un dominio un poco remoto con una fuerza seguramente débil. (62)

Se plantean ya aquí los dos términos de esa situación que Alonso había descubierto y subrayado en su comentario de "Arte poética": el poeta como objeto de contemplación, la poesía como compensación. Pero en la carta se ve más claro que en el poema, o en el comentario de Alonso, el papel salvador de la poesia, ya que no sólo salva al poeta sino que rescata al mundo, como se verá.

En una carta escrita pocos meses más tarde (septiembre 8), Neruda contará al amigo:

He completado casi un libro de versos: Residencia en la tierra, y ya verá usted cómo consigo aislar mi expresión, haciéndola vacilar constantemente entre peligros, y con qué sustancia sólida, uniforme hago aparecer insistentemente una misma fuerza. (62)

La reiteración que quiero subrayar aquí es la que está contenida en la última línea: "una misma fuerza". En una carta que había escrito a González Vera un mes antes se encuentra también la expresión "misma" que le sirve para dibujar esa continuidad del poeta y la poesía, esa fuerza.

... mis escasos trabajos últimos, desde hace un año, han alcanzado gran perfección, (o imperfección), pero dentro de lo ambicionado. Es decir, he pasado un límite literario que nunca crei capaz 
de sobrepasar, y en verdad mis resultados me sorprenden y me consuelan. (...) Todo tiene igual movimiento, igual presión, y está desarrollado en la misma tegión de mi cabeza, como una misma clase de insistentes olas. Ya verá usted en qué equidistancia de lo abstracto y lo viviente consigo mantenerme, y qué lenguaje tan agudamente adecuado utilizo. (63)

En otra carta a Eandi (abril 24, 1929) habrá de insistir, caracterizando su poesía de entonces con una lucidez que falta a muchos de sus críticos.

Es un montón de versos de gran monotonía, casi rituales, con misterio y dolores como los hacían los viejos poetas. Es algo muy uniforme, como una sola cosa comenzada, como eternamente ensayada sin éxito. (65)

La referencia a los viejos poetas y a una poesía monótona, casi ritual, permite comprender mejor el sentido profundo de su búsqueda. Porque se trata de algo má que de un hermetismo de poeta lúcido y con claves. La poesía a la que oscuramente aspira el Neruda de estos años es una poesía del misterio metafísico del mundo (no en el sentido contemporáneo de la palabra misterio, trivializado por la mala novela policial, el cine barato). El aspira a una poesía del rito. Poco a poco se va formando esa visión del poeta como vate, que llevará al reconocimiento de la visión profética. Ese reconocimiento se dará en una larga carta-diario a Eandi que Neruda comienza en octubre 5 y concluye en noviembre 21. Allí se encuentra esta frase:

El poeta no debe ejercitarse, hay un mandato para él y es penetrar la vida y hacerla profética: el poeta debe ser una superstición, un ser mítico. (67)

En las mismas cartas hay otros testimonios de la lucidez con que Neruda contemplaba su quehacer poético y esbozaba una poética. No sólo en lo que dice de sus propios versos, sino también en lo que dice de la poesía ajena, y en particular de la española y argentina de esos días, es posible encontrar testimonios de esa lucidez poética que tanto se le ha negado. Examinaré brevemente algunos de los pasajes relevantes de esta correspondencia.

La primera referencia literaria que nos interesa está en una carta a 
Eandi (septiembre 8, 1928). El amigo argentino le ha enviado Don Segundo Sombra, y Neruda agradece el envío con estas palabras:

Lo leí con sed y como si hubiera podido tenderme otra vez sobre los campos de trébol de mi país escuchando a mi abuelo y a mis tíos. ¿Verded que es algo grandioso y natural, algo conmovedor? Olor a extensión, a caballos, a vidas humanas, repetidos de una manera tan directa, comunicados tan completamente. (62)

El entusiasmo de Neruda por la novela de Güiraldes no es únicamente literatio. A través del libro, y de lo que el libro tiene de evocación nostálgica de una infancia y de una visión hondamente arcádica de la vida campesina, Neruda recupera su propia infancia campesina, su propio deslumbramiento ante la naturaleza, su nostalgia de un mundo natural y poblado por hombres como Don Segundo. Su valoración es literaria sólo en la medida en que la literatura se confunde con otras experiencias existenciales.

Pero donde su discrepancia con cierta poesía que estaba de moda entonces, se hace más explícita es en una carta de abril 24, 1929, al mismo Eandi. El recuerdo de Buenos Aires, de la Avenida de Mayo ("que entreví como en sueños"), de los grandes periódicos argentinos, de algunos escritores que conoció (Xul Solar, "un muchacho largo, de negro"), lo llevan a hablar de Borges, con el que establece ya una temprana discrepancia:

Me parece más preocupado de problemas de la cultura y de la sociedad, que no me seducen, que no son humanos. A mí me gustan los grandes vinos, el amor, los sufrimientos y los libros como consuelo a la inevitable soledad. Tengo hasta cierto desprecio por la cultura; como interpretación de las cosas me parece mejor un conocimiento sin antecedentes, una absorción física del mundo, a pesar y en contra de nosotros. La historia, los problemas del "conocimiento", como los llaman, me parecen despojados de dimensión. ¿Cuántos de ellos llenarían el vacío? Cada vez veo menos ideas en torno mío, y más cuerpo, sol y sudor. Estoy fatigado. (64)

Creo que la frase clave aquí es: "una absorción física del mundo". Por medio de los sentidos y por medio de las emociones, el poeta se abre camino dentro del mundo y lo absorbe físicamente. Ia cultura, la "literatura", los libros, no pueden ser sustitutos de esa absorción. Por eso no es extraño que rechace (ya) a Borges y que le parezca más interesante 
el excéntrico Xul Sclar, ese personaje casi desconocido de las letras argentinas del periodo, amigo de Borges, ilustrador de alguno de sus libros, e inventor no sólo de monstruos gráficos sino de un lenguaje nuevo del que Borges tomó muchos de los rasgos de la lengua de Tlön en su célebre relato. ${ }^{10}$ Preferir Xul Solar a Borges significa, en ese momento de la carrera de Neruda, preferir a quien se comunica con las zonas más oscuras del hombre y rechazar al poeta ultraísta, lúcido y lúdico que era entonces Borges. Que esta visión de Neruda es parcial, en más de un sentido, e injusta, no me parece necesario decirlo ahora que sabemos todo lo secreto y ritual que encierra la literatura de Borges. ${ }^{11}$ Pero lo que me parece relevante subrayar aquí es que en estas objeciones de Neruda a una cierta literatura de entonces se encuentra el mismo rechazo, la misma búsqueda, que en sus poemas proféticos. También en la larga carta-diario a Eandi de octubre 5-noviembre 21 hay un párrafo sobre la nueva literatura de entonces que merece destacarse.

. .ya ve usted qué pobreza existe en la poesía en castellano, las gentes han perdido todo temperamento y se dedican al ejercicio intelectual con placer, como si se tratara de un sport, y aún en esa calidad, todos me parecen bien mediocres jugadores. El Lugones tan denigrado, me parece en verdad rico de dotes, su poesía me parece casi siempre poética; es decir, legítima, aunque anacrónica y barroca. (67)

Para situar mejor este juicio, tan global y lapidario, hay que recordar que Neruda escribe en los años en que la generación ultraísta argentina se había dedicado con esmero a burlarse de Lugones, a atacarlo por su poesía y por su ideología de derechas. En ese momento, Neruda ve la calidad poética de Lugones con una claridad que faltaba a los poetas de su generación. Sólo muchos años más tarde, Borges (uno de los negadores) reconoció que los poctas ultraístas habían estado repitiendo a Lu. gones y que Lunario sentimental ya había descubierto, en 1909, la ruta de la nueva poesía. O para decitlo con sus inimitables palabras:

10 Para una aplicación borgiana del lenguaje inventado por Xul Solar, véase "Tlön, Uqbar, Orbis Tertius", in El jardin de senderos que se bifurcan (Buenos Aires, Editorial Sur, 1941), p. 18. Los dos libros de Borges ilustrados por Xu1 Solar son: El idioma de los argentinos (Buenos Aires, M. Gleizer, editor, 1928) y Un modelo para la muerte, falsa novela policial escrita en colaboración con Adolfo Bioy Casares y publicada con el seudónimo de "B. Suátez Lynch" (Buenos Aires, Oportet \& Hacteses, 1946). Ambos libros tienen viñetas de Xul Solar.

11 Véase Emir Rodríguez Monegal: Borgès par lui même (Paris, Editions du Suil, 1970); especialmente las pp. 87-113. 
...el múltiple Lugones, cuya obra prefigura casi todo el proceso ulterior, desde las inconexas metáforas del ultraísmo (que durante quince años se consagró a reconstruir los borradores del Lunario sentimental)...12

Es cierto que aqui Borges, por modestia, olvida señalar la importancia de su propia obra para la configuración del ultraísmo argentino, pero aún así es interesante ver cómo, a la distancia de algunos años (las cartas de Neruda son de 1929, el texto de Borges de 1941) ambos coinciden en la valoración de Lugones. En lo que no coinciden es en la valoración de la poesía misma. Neruda elogia a Lugones como poeta general, con el que puede encontrar puntos de contacto, y para deprimir a los jóvenes que ven sólo el aspecto lúdico, deportivo, de la poesía. Borges elogia a Lugones como su maestro, un precursor.

Pero al margen de esta imaginaria polémica, conviene subrayar, una vez más el apartamiento de Neruda de lo que pasaba por poesía en los años veinte. Ese apartamiento se extiende no sólo a la poesía argentina, sino a la hispanoamericana y española de los mismos años. Sólo al volver a España en 1934 encontrará Neruda en García Lorca y Alberti, en Aleixandre y Miguel Hernández una poesía con la que pueda dialogar de igual a igual. De esa poesía él será pronto la cabeza más visible.

\section{IV}

Es muy sabido que Neruda habría de renegar de la poesía de Residencia en la tierra. La experiencia que significó para él la guerra civil española y la sangre corriendo por las calles de Madrid, trajo una rup. tura dramática con su poesía de Residencia. En varios lugares, pero sobre todo en el poema que se titula, "Reunión bajo las nuevas banderas", y en algunos fragmentos de "España en el corazón (1937), recogidos ambos en Tercera residencia (1947), el poeta habrá de renunciar a su paso de lobo, aceptará la solidaridad con todos los hombres y convertirá su poesía en arma de combate. En los años que siguen a la guerra civil española, los años de la segunda guerra mundial, de la guerra fría, de Corea, Neruda habrá de insistir una y otra vez en la necesidad de una poesía que sea como una ametralladora, habrá de denunciar a los poetas de la evasión, habrả de alinearse como poeta comprometido y practican.

12 Jorge Luis Borges, Silvina Ocampo y Adolfo Bioy Casares: Antología poética argentina (Buenos Aires, Editorial Sudamericana, 1941), p. 8. 
te del realismo socialista. En unas declaraciones que hace en México a Alfredo Cardona Peña, en momentos en que se publica alli el Canto geneval (1950), dirá en forma lapidaria:

Contemplándolos ahora, considero dañinos los poemas de Residen. cia en la tierra. Estos poemas no deben ser leídos por la juventud de nuestros países. Son poemas que están empapados de un pesimismo y angustia atroces. No ayudan a vivir, ayudan a morit. ${ }^{13}$

En cierto sentido, Neruda parece estar dando aquí la razón a Alonso y a su insistencia en el aspecto puramente negativo de estos poemas. Creo que el poeta olvida en este momento la visión profética que él mismo había subrayado en su poesía. Creo que el olvido es deliberado y corres. ponde a una metamorfosis de su persona similar a la que sufre Goethe después de su viaje a Italia. Así como el poeta alemán rechazará entonces la obra juvenil y hasta la reescribirá en otra clave, Neruda rechaza su Residencia para situarse en otra estética. No es posible estudiar ahora en detalle esa metamorfosis que Alonso calificó de "conversión" y que ha sido examinada ya por la crítica. Lo que sí me interesa subrayar es que la negación de Neruda define un momento de su poesía, ese momento de los años combativos que corren de 1936 hasta 1958, pero no define toda su poesía posterior. En los años cincuenta, y a partir de Los versos del capitân (1953), hay una nueva metamorfosis de su poesía, metamor. fosis que habrá de encontrar expresión implícita en el volumen que se llama Estravagario (1958). A partir de este libro, y sin renunciar a sus deberes políticos, a la solidaridad, al canto del Tercer Mundo, Neruda deruelve a su poesía un acento que había desaparecido. El acento que estaba en la raíz de sus búquedas apasionadas de los años veinte y treinta, el acento profético.

Para reconocer con más detalle el proceso profundo que se produce en el poeta a largo de esos años de rechazo explícito del don profético, conviene volver atrás y examinar algunos textos que sirven de enlace entre Residencia y Estravagario. Tal vez los más importantes sean los cuatro prólogos que Neruda escribió para sendos números de la revista Caballo verde para la poesia que se publicó en España bajo su dirección y con el apoyo de los poetas jóvenes. Son textos muy conocidos, y aquí

13 Alfredo Cardona Peña: "Pablo Neruda: Breve historia de sus libros", in Cuadernos Americanos (México, diciembre 1950). Reproducido y ampliado en Pablo Neruda y otros ensayos (México, De Andrea, 1955), del mismo autor. Cito por una transcripción en El viajero, p. 12. 
sólo examinaré algunos aspectos. Elijo el primero que se titula "Sobre una poesía sin pureza".

Así sea la poesía que buscamos, gastada como por un ácido por los deberes de la mano, penetrada por el sudor y el humo, oliente a orina y azucena, salpicada por las diversas profesiones que se ejercen dentro y fuera de la ley.

Una poesía impura, como un traje, como un cuerpo, con manchas de nutrición, y actividades vergonzosas, con arrugas, observaciones, sueños, vigilias, profecía, declaraciones de amor y de odio, bestias, sacudidas, idilios, creencias políticas, negaciones, dudas, afirmaciones, impuestos. ${ }^{14}$

Este texto fue publicado en octubre 1935, ocho meses antes de que estallara la guerra civil, pero ya en él se puede descubrir un cambio fundamental en la estética de Neruda. Al atacar el concepto de poesía pura, no sólo sienta una posición de combate frente a Juan Ramón Jiménez y muchos de los jóvenes poetas que entonces seguían a este maestro.15 Neruda hace algo más: ensancha el campo de la poesía para incorporar todo en ella. Si bien es cierto que continúan predominando muchas notas negativas (el texto concluye exaltando la melancolía), no son sólo las notas negativas las que caracterizan esta estética. Hay incluso lugar para las declaraciones políticas. Hay lugar para los sueños y las profecías. Es, precisamente, en esta actitud de incluirlo todo que encuentra Neruda la clave de su nueva estética.

Poco después, al estallar la guerra civil española, Neruda planteará los términos de su conflicto, de su "conversión", en los célebres y celebrados versos de "España en el corazón". Con el subtítulo de "Explico algunas cosas", el poeta declara:

Preguntatéis: $Y$ dónde están las lilas?

$Y$ la metafísica cubierta de amapolas?

$Y$ la lluvia que a menudo golpeaba

sus palabras, llenándolas

de agujeros y pájaros?

Os voy a contar todo lo que me pasa.

$$
\text { (O. C., I, 275) }
$$

\footnotetext{
14 Prólogo al número primero de Caballero verde para la poesía (Madrid, octubre 1935). Transcripto en $O . C$., II, 1040.

15 Véase El viajero, pp. 86-90, para una crónica más detallada de las discrepancias de Pablo Neruda con Juan Ramón Jiménez y los suyos.
} 
A continuación, el poeta evoca su casa en Madrid, sus amigos, el ataque franquista, la sangre de los niños corriendo por las calles, y concluye:

Preguntaréis por qué su poesía no nos habla del sueño, de las hojas, de los volcanes de su país natal? Venid a ver la sangre por las calles, Venid a ver la sangre por las calles, venid a ver la sangre por las calles! (O.C., I, 277)

Es la hora de la espada. El poeta debe salir a la calle a luchar junto a los suyos.

\section{V}

En otro alto momento de su poesía, en "Alturas de Macchu Picchu" (1945), recogido en el Canto general, hará tambiẻn el poeta recuento de su conversión y expresará su nuevo credo poético. Pero el texto es demasiado largo y conocido para que sea necesario citarlo aquí, entero. Bastará señalar que está compuestó de doce poemas, ordenados en una secuencia que puede escindirse, temáticamente, en dos series. En los cinco primeros (I.V), el poeta repasa su aventura vital y poética desde las angustias de Residencia en la tierra hasta el descubrimiento personal, un día de 1943, de esta ciudad de piedra, ombligo del mundo precolombino. En los siete poemas restantes (VI-XII), Neruda se vuelve sobre Macchu Picchu para descubrir no sólo el secreto de esas piedras mudas sino su propio secreto de viajero sin raíces. Al revelársele la solidaridad con aquellos hombres que hicieron la ciudad, piedra sobre piedra, el poeta descubre su entronque profundo con una tierra, una raza, una hora, en la que tiene sus verdaderas raíces. De aquí arranca el canto. Porque el poeta también descubre allí la confirmación de una vocación poética: la del cantor de América. El poema es, en este sentido, profético. Con él empieza verdaderamente el Canto general.

Citaré unos versos que permiten comprender exactamente este proceso final. Constituyen el último poema, el XII:

Sube a nacer conmigo, hermano.

Dame la mano desde la profunda zona de tu dolor diseminado. 
No volverás del fondo de las rocas.

No volverás del tiempo subterráneo.

No volverá tu voz endurecida.

No volverán tus ojos taladrados.

Mírame desde el fondo de la tierra, labrador, tejedor, pastor callado: domador de guanacos tutelares: albañil del andamio desafiado: aguador de las lágrimas andinas: joyero de los dedos machacados: agticultor temblando en la semilla: alfareto en tu greda derramado: traed a la copa de esta nueva vida vuestros viejos dolores enterrados. Mostradme vuestra sangre y vuestro surco, decidme: aquí fuí castigado, porque la joya no brilló o la tierra no entregó a tiempo la piedra o el grano: señaladme la piedra en que caísteis y la madera en que os crucificaron, encendedme los viejos pedernales, las viejas lámpatas, los látigos pegados a través de los siglos en las llagas y las hachas de brillo ensangrentado.

Yo vengo a hablar por vuestra boca muerta.

A través de la tierra juntad todos los silenciosos labios derramados y desde el fondo habladme toda esta larga noche, como si yo estuviera con vosotros anclado.

Contadme todo, cadena a cadena, eslabón a eslabón, y paso a paso, afilad los cuchillos que guardasteis, ponedlos en mi pecho $y$ en mi mano, como un río de rayos amarillos, como un río de tigres enterrados, y dejadme llorar, horas, dias, años, edades ciegas, siglos estelares. 
Dadme el silencio, el agua, la esperanza.

Dadme la lucha, el hierto, los volcanes.

Apagadme los cuerpos como imanes.

Acudid a mis venas y a mi boca.

Hablad por mis palabras y mi sangre.

(O. C., I, 347.348)

Un doble proceso de identificación se produce en este último poema. Por un lado, ahora concluye la identificación del poeta con el hombre que construyó la ciudad de piedra; proceso que estaba anunciado en la secuen. cia de poemas que preceden a este último pero que aqui alcanza una claridad total. El poeta dirá sus hermanos que le hablen en esta larga noche,

como si yo estuviera con vosotros anclado.

La solidaridad del poeta con sus hermanos, tan humildes y desgraciados, queda explícitamente indicada. Es una etapa más, y decisiva, de esa solidaridad con los demás hombres que Neruda ya había descubierto en el poema, "Reunión bajo las nuevas banderas", de la Tercera Residencia, y que había encontrado tan poderosa fórmula poética en España en el corazón. Pero hay algo más que solidaridad aquí. Hay, y esto es lo principal, el descubrimiento de un aspecto central de la vocación del poeta: a partir de este momento, por boca del poeta hablarán los hombres que no tienen voz. Por eso el poeta dirá ahora:

Yo vengo a hablar por vuestra boca muerta.

Y terminará el poema, y la secuencia entera, con este verso:

Hablad por mis palabras y mi sangre.

¿Cómo no reconocer aquí un proceso de identificación que no es sólo solidaridad (en el sentido político y social de la palabra) sino algo más y diferente: la vocalización, el poder de vocalizar que tienen los poetas y que los convierte en verdadera vox populi? Aunque el benemérito Diccionario de la Academia no reconoce este sentido, él es bastante común en inglés, por lo menos desde 1858, según nos informa el Shorter Oxford English Dictionary:

Vocalize (...) 3. To endow with voice; to render vocal or articulate $1858 .^{16}$

16 Véase The Shorter Oxford English Dictionary (Oxford, 1962, tercera ediciôn), p. 2367. 
De manera que lo que hace Neruda al terminar "Alturas de Macchu Picchu" es reconocer este don de vocalizar, de dar voz a la palabra muda del pueblo, que será su vocación fundamental desde ese momento. Es posible reconocer aquí también un proceso similar al que registra la poesía de Walt Whitman en sus Leaves of Grass; proceso que, por otra parte, ya he indicado en algunas páginas de El vialjero inmóvill. ${ }^{17}$ Aquí me interesa subrayar que el proceso de vocalizaciớn se une, por finas raíces subterráneas, con el proceso de la profecía. Al identificarse con el hombre desaparecido de la América precolombina, al dar voz a su lengua muerta, Neruda cumplirá una profecía que es la del continente entero, en las infinitas dimensiones no sólo espaciales sino temporales. Testigo del hoy y del ayer, observador y victima, cantor y actor del drama secular, Neruda está en todas partes al mismo tiempo porque no es ya un hombre, ni un poeta, sino una voz que viene desde el fondo de los tiempos y que canta hoy, vocalizando todas las voces mudas del Nuevo Mundo.

Esta interpretación de "Alturas de Macchu Picchu", que parece obvia si se analiza el poema rectamente, ha escapado a cierto sector de la crítica norudiana. Impresionados muchos por la ideología comunista del poeta, no han estudiado adecuadamente la "ideología" del poema. Lo que ha confundido a la crítica sobre este aspecto hondamente profético del poema son, tal vez, las posteriores declataciones explicitas de Neruda sobre el realismo socialista; sus largos catálogos de denuncia política dentro y fuera del Canto general; los poemas dedicados a la lucha pre-electoral chilena de esos días, a a la defensa del mundo socialista durante la guerra fría. No hay que olvidar que "Alturas de Macchu Picchu", y todo el Canto general, por otra parte, se escribe en los años que van hasta $1950 \mathrm{y}$ en que Neruda no sólo ingresa en el Partido comunista chileno sino que se convierte en Senador por dicho partido y, más tarde, es perseguido y forzado al exilio por su misma actividad política. Pero la ideología del senador Pablo Neruda y la ideología del poema son cosa distinta. La ideología del poema es (como he tratado de indicar ya) mucho más profética que materialista, está más cerca de William Blake, de Hugo, de Whitman, que de Marx o de Lenin.

Sin embargo, lo que cierta crítica ha subrayado es sólo el descubrimiento de la solidaridad por parte del poeta, olvidando el descubrimiento (mucho más decisivo para la poesía misma) de ese poder de vocalizar, de convertirse en verdadera vox pupuli. Tal vez quien ha expresado más

17 En las páginas 17-20 de El viajero, se indica brevemente el origen de la concepción whitmaniana de la persona poética que Neruda aprovechará en muchos nomentos de su obra, y en particular en el Canto general. 
insistentemente este punto de vista marxista es Hernán Loyola en su libro, Ser y morir en Pablo Neruda (1967). En esta obra, así como en el prólogo a la Antología esencial, de Neruda (1971), Loyola llega a la conclu. sión que en el poema Neruda descubre "la posibilidad de perpetuarse en la vida concreta de la comunidad a que pertenece". ${ }^{18}$ Para llegar a esa conclusión, Loyola analiza incompletamente el poema y la circunstancia en que fue escrito. Su punto de vista queda expresado en un par de lugares, de esta forma:

Tenemos la certeza de que la estructura de "Alturas de Macchu Picchu" sólo se explica si entendemos este poema como el testimo. nio poético de una grande y definitiva decisión, como el reflejo poético de su adhesión al pensamiento, a la acción política y a la disciplina del Partido Comunista de Chile. (200)

Digamos, en suma, que el ingreso definitivo de Neruda a las filas del Partido Comunista de Chile y la composición de "Alturas de Macchu Picchu" son dos expresiones gemelas de un mismo hecho interior. Ambas se explican mutuamente y se complementan. (202)

En otro lugar de su estudio, insiste Loyola en que "el valor máximo" del poema reside en haber condensado "el complejo proceso que discurría en la conciencia de Pablo Neruda" (235). Creo que la palabra clave aquí es, precisamente, conciencia. El crítico matxista pone demasiado el acento en la conciencia del poeta. Si la adhesión al Partido comunista chileno puede ser situada en el nivel de la conciencia, ya que es un acto que compromete políticamente al ciudadano Pablo Neruda, es indudable que la escritura del poema está situada a otros niveles. No sólo al de la conciencia política del ciudadano.

De ahí que en su esfuerzo por explicar el poema, Loyola pierde de vista por completo el proceso de lo que he llamado la vocalización. El sólo ve la solidaridad social, lo que está bien pero no es suficiente. Es significativo, por eso mismo, que en su análisis, el poema ẌII sea considerado únicamente en el aspecto social:

Neruda evoca al hombre de Macchu Picchu llamándolo por su oficio, porque a través de su oficio, de su trabajo, ese hombre inscribió su vida personal en la de su comunidad. (...) Porque el trabajo

18 Véase Hernán Loyola: Ser y morir en Pablo Neruda (Santiago de Chile, Editora Santiago, 1967), p. 239. En el prólogo a la Antología esencial, de Pablo Neruda (Buenos Aires, Editorial Losada, 1971), p. 26, Loyola repite textualmente esta frase. 
(que el poeta siente entaizado en una tierra que también es suya), estableció entre Neruda y el hombre de. Macchu Picchu un vínculo de fraternidad más allá del tiempo. Sólo quedó la ciudadela de piedra, como un testimonio inmóvil y silencioso de la vida interrumpida, como un reflejo de esa vida; reflejo que proyectado en el tiempo vacío, sin hombre, sin historia, encontró de pronto a un hombre capaz de reimprimirle sentido a su movimiento ciego, capaz de conectar aquel remoto pretérito a nuestro hoy, de reanudar el hilo cortado. Y Pablo Neruda, ante las ruinas, se sintió llamado a esta faena de enlazar a su propia vida ese hilo cortado hace siglos: 'Sube a nacer conmigo, hermano'. ¿De qué modo cumplirá su cometido? A través de su propio oficio, el de poeta: (240-241)

A continuación Loyola cita algunos versos del poema. Como se puede ver, el crítico marxista reconoce la relación social del poeta con el hombre que construyó la ciudad de piedra, y reconoce que con su oficio de poeta, Neruda reanuda el interrumpido hilo y hace ingresar la historia en el poema. De acuerdo. Pero lo que Loyola no distingue es precisamente la naturaleza de la operación poética (no social) que se describe en el poema. Esa operación que he llamado de vocalización. Aquí está el punto central del poema, y de la visión profética de Neruda. La solidaridad del poeta con el hombre de Macchu Picchu, es decir: con el hombre americano, no ocurre simplemente al nivel de una conciencia política sino a nivel de una operación profética.

La distinción me parece importante. De no hacerla, habría que creer, en efecto, que la "conversión" política de Neruda equivale a una abjuración total de su don poético más profundo. En realidad, lo que ha ocurrido es un proceso poético mucho más complejo. Por el camino de la emoción y de la identificación apasionada (y no sólo por el camino de la concien. cia), Neruda ha llegado a descubrir ese poder de la vocalización que el poeta, oscuramente profético de Residencia en la tierra, buscaba sin saberlo. Es cierto que debido a la ideología consciente del poeta, la visión profética de "Alturas de Macchu Picchu" habrá de excluir la melancolía. Pero no abolirá los caminos profundos de la profecía. Sólo que ahora, el don profético ascenderá a la superficie de la conciencia del poeta, se hará más explícito y hasta programático, acompañará más dócilmente la formulación ideológica del socialismo soviético. Pero en lo profundo, en la raíz, las cosas no habrán cambiado tanto, como lo demuestra una lectura profética del Canto general entero ${ }^{19}$

18 Para un estudio más general de este libro véase El viajero, pp. 235-254. 
Desde otro campo de la crítica ideológica, el católico, se ha tratado de leer "Alturas de Macchu Picchu" con un método que es similar al de Loyola: en vez de descodificar la "ideologia" del poema, se ha tratado de sobreimponerle una ideología previa, la del crítico. Me refiero, es claro, a la lectura que hace Robert Pring-Mill en el prólogo a la edición bilingüe inglesa de The Heights of Maccbu Piccbu ${ }^{20}$ En cuatro páginas de apretado texto, el crítico inglés busca y encuentra semejanzas con Eliot (un par de veces se cita Burnt Norton, del poeta anglo-norteamericano); indica el carácter de "letanía" que tiene un fragmento significativo del poema IX; alude a la coincidencia del lenguaje que emplea Neruda con el lenguaje cristiano al referirse a la agonía del hombre de la ciudad de piedra. Es posible discutir con Pring-Mill sus aproximaciones a Eliot. Creo que carga un poco la mano en ambas, y no sería difícil mostrar que ellas pertenecen más a un topos literario que a una influencia ideológica. Pero pasemos. También es discutible alguna otra afirmación. Pero lo que me parece totalmente insostenible es una lectura que hace Pring-Mill de un verso del poema VII. Citaré el pasaje entero:

This image of the black cup, trembling - because they trembleas they tip it back, prepares the way for the contrasting image of Macchu Picchu as a 'permanence of stone... raised like a chalice' [VII]. The religious overtones of such an image seems quite deliberate, and I think that Neruda often uses Christian imagery (part of the general Catholic heritage of South America) to heigh. ten a vital point much as Renaissance poets used the pagan myths, bringing the textured associations of an extended frame of reference into play without implying the literal truth of its conceptual framework. (7).

La explicación que ofrece Pring-Mill resulta cándida y hasta aceptable, a primera vista. No es posible negar que Neruda escribe en una lengua impregnada de asociaciones católicas. Si lo que dice Pring-Mill se refiriera, por ejemplo, al uso de la palabra "crucificar" en el poema XII ("y la madera en que os crucificaron", dice el poeta dirigiéndose a los hombres mudos), no sería posible disentir con él. Allí Neruda, explícitamente, utiliza una expresión que en su sentido metafórico aunque

20 Véase Pablo Neruda: The Heights of Macchu Picchu (London, Jonathan Cape, 1966). La traducción es de Nathanael Tarn. El prólogo de Robert PringMill ocupa las Pp. 7-13. Hay edición norteamericana de la obra (New York, Farrar, Straus \& Giroux, 1967). 
popular deriva obviamente de la tradición cristiana. Pero la observación de Pring-Mill se reficre a dos versos que en español dicen literalmente:

Pero una permanencia de piedra y de palabra:

la ciudad como un vaso se levantó en las manos

La palabra clave aquí es "vaso". Pring-Mill parece olvidar que en español existe la palabra "cáliz". Es de suponer que si Neruda hubiera querido indicar alguna asociación cristiana hubiera empleado esta palabra, y no "vaso" que enfáticamente carece de esa asociación. El error de PringMill, que se proyecta sobre el traductor, Nathanael Tarn, es significativo de ese tipo de lectura sobreimpuesta. Aunque proviene de otras coordenadas ideológicas, Pring-Mill coincide con Loyola en seguir la línea de su propio discurso y no la del poema que comenta. Entretanto, se les escapa a ambos la dimensión realmente poética de la "ideología" del poema. Esa dimensión que considero profética.

En un libro de transición, un libro que ha sido bastante mal leído por la crítica, que ha visto en él sólo lo más superficial, volverá Neruda un par de veces a definir su nueva poética. Me refiero naturalmente a las Odas elementales (1954). Se encuentran allí dos poemas, "Oda a la crítica" y "Oda a la poesía" que sintetizan, muy explícitamente, una poética nueva, la poética del realismo socialista, que es la doctrina oficial del mundo comunista de entonces. En la primera Oda, el poeta opone a la crítica, para él siempre malintencionada, enemiga, cruel, la actitud de los hombres sencillos que se acercan a su poesía sin prevenciones ni perjuicios y la usan para sus propios fines particulares.

En una línea de mi poesía secaron ropa al viento.

Comieron mis palabras, las guardaron junto a la cabecera, vivieron con un verso, con la luz que salió de mi costado.

$$
\text { (O.C., I, 1042) }
$$

En esta última línea, el poeta agrega a la concepción de la poesía como algo útil y utilitario, ese deslumbramiento de la creación que va 
más allá del mundo visible. Al utilizar una metáfora de cuño bíblico - la luz que sale de su costado, como la mujer sale de la costilla de Adán por la intervención maravillosa de la mano de Dios-, Neruda parece aludir a esa vocación secreta y misteriosa, profética en el viejo sentido de los viejos poetas, a que hacía alusión en su primera "Arte poética". ${ }^{21}$

El otro poema es más explícitamente edificante. El poeta celebra su casi cincuentenario conyugal con la poesía y muestra cómo ha cambiado su actitud hacia ella. Hablándole directamente llegará a decir:

Tanto anduve contigo

que te perdí el respeto.

Dejé de verte como

Náyade vaporosa,

te puse a trabajar de lavandera,

a vender pan en las panaderías,

a hilat con las sencillas tejedoras,

a golpear hierros en la metalurgia.

Yo te pedí que fueras

utilitaria y útil,

como metal o harina,

dispuesta a ser arado,

herramienta,

pan $y$ vino,

dispuesta, Poesía,

a luchar cuerpo a cuerpo

y a caer desangrándote.

(O. C., I, 1146-1148)

Pero no será en este primer libro de las Odas, ni en los siguientes, sino en Estravagario (1958) donde se descubra que la vena profética (soterrada, o ignorada por esta poesía edificante) no estaba del todo agotada. En muchos pasajes de ese libro espléndido hay indicaciones ex. plícitas de un cambio en la poética que corresponde (una vez más) al camibio en la situación existencial del poeta. Indicaré sólo algunos. Así en un poema titulado "Dulce siempre" hay esta estrofa:

Quiero versos de tela o pluma

que apenas pesen, versos tibios

21 En las Nuevas odas elementales hay otra "Oda a la crítica", en que Neruda agradece la guía que la crítica le ha dado. Véase O.C., I, pp. 1235-1237. 
con la intimidad de las camas

donde la gente amó y soñó.

Quiero pocmas mancillados

por las manos y el cada día.

$$
\text { (O. C., II, 142) }
$$

¿Cómo no reconocer en estas líneas un eco, a través de casi un cuarto de siglo de distancia, de aquel manifiesto altivo sobre una poesía sin pureza? Aquí vuelve a sonar la misma nota. Pero será en uno de los poemas iniciales del libro, "Pido silencio", donde Neruda reivindique el derecho del hombre y del poeta, es decir: de la poesía, a hundir sus raíces en lo más profundo y oscuro.

Sucede que soy y que sigo.

No será, pues, sino que adentro

de mí crecerán cereales,

primero los granos que rompen

la tierra para ver la luz, pero la madre tierra es oscura:

y dentro de mí soy oscuro:

soy como un pozo en cuyas aguas

una noche deja sus estrellas

y sigue sola por el campo.

$$
\text { (O. C., II, 75) }
$$

Lo que así queda apuntado en la línea y en la entrelínea de muchos poemas de Estravagario habrá de encontrar una formulación explícita en un poema del Memorial de Isla Negra (1964). Publicado seis años después de aquel libro, el nuevo poema se titula "La poesía" y recapitula la experiencia primordial del joven poeta: el descubrimiento de la poesía. ${ }^{22}$ Lo daré íntegro.

Y fue a esa edad. . Llegó la poesía

a buscarme. No sé, no sé de dónde

salió, de invierno o río.

No sé cómo ni cuándo,

no, no eran voces, no eran

22 Para el periodo de la poesía de Neruda que va de Estravagario a Memorial de Isla Negra inclusive, véase El viajero, pp. 289-332. 
palabras, ni silencio,

pero desde una calle me llamaba, desde las ramas de la noche, de pronto entre los otros, entre fuegos violentos

o regresando solo, allí estaba sin rostro

y me tocaba.

Yo no sabía qué decir, mi boca no sabía

nombrar, mis ojos eran ciegos, y algo golpeaba en mi alma, fiebre o alas perdidas, y me fui haciendo solo, descifrando aquella quemadura, - y escribí la primera línea vaga, vaga, sin cuerpo, pura tontería, pura sabiduría

del que no sabe nada, y vi de pronto

el cielo

desgranado

y abierto,

planetas,

plantaciones palpitantes,

la sombra perforada, acribillada

port flechas, fuego y flores,

la noche arrolladora, el universo

Y yo, mínimo ser, ebrio del gran vacío, constelado,

a semejanza, a imagen

del misterio, me sentí parte pura del abismo, 
rodé con las estrellas, mi corazón se desató en el viento.

(O. C., II, 506.507)

Parece inevitable relacionar este poema con el "Arte poética" de la primera Residencia. El sistema de imágenes es similar y las referencias concretas -al viento, a la noche, al día que arde y deja fiebre o quemaduras en la piel del poeta - muestran hasta qué punto el poeta es capaz de reconstruir, a la distancia de tantos años, lo que fue esa experiencia deslumbrante, $y$ aterradora, del primer encuentro con la poesía. Lo único que falta en la evocación es una referencia explícita a lo profético. Pero al hablar de su identificación con el misterio, con el abismo, con las estrellas, Neruda está eludiendo a ese sentimiento de unidad con el cosmos que está en la raíz de su poesía. De aquí arranca su profetismo. Por eso, en un poema del mismo libro y que se titula, tan reveladoramente, "Pampoesía", Neruda habrá de dejar caer este verso definitivo.

El primer sello es condición oscura,

(O. C., II, 531)

Condición oscura, sí. Ahora el poeta puede volver a reconocer su condición oscura, puede volver a asumir el lado de sombra, puede volver a ser vate, profeta. Pero profeta de una realidad menos uniformemente sombría, menos melancólica que la de las dos primeras Residiencids. Una realidad, sin embargo, que reconoce el misterio y los abismos, las estrellas y ese fondo oscuro, contradictorio, que yace en el centro de cada uno de nosotros. A partir de Estravagario, el poeta ha vuelto a aceptar la luz y la sombra, el sí y el no, lo conocido y lo desconocido.

El nuevo rumbo de su poesía lo llevará al recuento apasionado de su propia biografía. Por dos veces, en la prosa de las Memorias de $O$ Cruzeiro (1962) y en el verso del Memorial de Isla Negra (1964), Neruda recontará su vida al tiempo que metamorfoseará su persona poética y bio. gráfica por medio de la escritura. Pero no es en estas autobiografías explícitas en donde podrá verse mejor la soterrada vena profética de esta última etapa, sino en uno de los últimos libros del poeta, libro que no ha podido merecer aún de la crítica la necesaria atención. Me refiero, es claro, a La espada encendida (1970). ${ }^{23}$ En esa larga secuencia de ochenta y siete poemas, Neruda cuenta la historia del primer hombre y la primera mujer, del amor que nace entre ellos como una conmoción y los arrebata, del

23 Pablo Neruda: La espada encendida (Buenos Aires, Editorial Losada, 1970). 
liuego que amenaza destruitlos, del agua que los salva, de un Dios que muere y de dos seres que descubren su divinidad. El libro se abre con una cita del Génesis (III, 24) y se cierra con otra cita, de un libro de Julio Vicuña Cifuentes (Mitos y supersticiones de Chile, 1919), en que se habla de la desaparecida, o tal vez inexistente, Ciudad de los Césares, en el Sur de Chile. Neruda junta la historia original bíblica, con su pareja adánica y el castigo por el conocimiento del amor y la espada encendida con que Dios guarda (después de la caída) el camino del árbol de la vida, con el viejo mito americano de esa ciudad de oro y plata, imagen del paraíso terrenal. Pero lo que da un sesgo muy nerudiano al poema, es que la pareja original vive su experiencia de la vida en el más intenso nivel erótico. Su soledad compartida los aísla del mundo y crea un mundo para ellos; un mundo que será amenazado por el fuego del volcán; un mundo que ellos reconstruirán con su amor a partir de la muerte de Dios.

Es muy fácil reconocer aquí la presencia de un tema que recorre la obra entera de Neruda, desde los primeros poemas de amor de Crepuscu. lario, pasando por los Veinte poemas, ciertas secuencias de las primeras Residencias, "Las furias y las penas", el incandescente poema quevedesco de la Tercera Residencia, hasta llegar a los libros explícitamente eróticos: Los Versos del Capitán, Cien sonetos de amor, ciertas secuencias del Me. morial de Isla Negra, todo el comienzo de Barcarola. En esos textos, Neruda ha contádo y cantado al amor, a los amores, a su propio erotismo desencadenado. Lo que es nuevo en la espada encendida es que ahora el poeta no canta al amor en primera persona, o bajo la transparente máscara del Capitán de los famosos Versos. Ahora Neruda canta al amor de Rhodo, "pétreo patriarca", y de Rosía, "hija cesárea, labradora". Ahora asume la máscara del narrador épico, y después de una breve introduc. ción en verso, "El poeta comienza a cantar", da paso a lo que él llama "esta sonata negra". En muchas partes del libro, los personajes toman la palabra; en el último poema, hablan alternadamente. Neruda, ese yo incontenible de toda la obra anterior, está presente sólo un par de veces $y$ en forma harto discreta.

Pero si Neruda, como poeta, no es el protagonista del poema, su Rhodo es (naturalmente) una máscara o persona del poeta. Pero una máscara dramática, y no lírica. Tal vez influido por los experimentos teatrales que significan su traducción de Romeo y Julieta (1964) y su cantata popular, Muerte y fulgor de Joaquin. Murieta (1967), Neruda ha elegido esta vez personificarse en un ser que no reproduce sino los aspectos esenciales de su yo. No es éste el lugar de analizar detalladamente el largo poema. Bastará indicar que aquí Neruda concentra, en cifra, su des- 
tino entero de viajero y de desterrado, de amante sucesivo y solitario, de ser condenado a recorrer el mundo con una enorme culpa, de espíritu capaz de encontrar siempre en definitiva una salida a la negra melancolía y a la destrucción del mundo. Al proclamar la muerte de Dios y la acep. tación de su propia divinidad, los personajes de La espada encendida asumen su destino final. Al crearlos en la escritura del poema, Neruda asume su destino profético.

Como los viejos libros de que hablaba en las cartas a Eandi, éste tam. bién es monótono y repetitivo. Varias veces cuenta la soledad de Rhodo; varias veces reitera la fuga de Rosía de la Ciudad cesárea; varias veces describe su primer encuentro erótico; varias veces narra la erupción volcánica que convertitá el río de lava en la espada encendida del Génesis; varias veces el mar aparecerá como el refugio, la salvación, el seno materno. Como los poetas de la profecía (Blake, Hugo, Whitman, Lautréamont), Neruda habrá de volver una y otra vez, incansable, a los mismos motivos, los mismos paisajes, las mismas personas. En esa circularidad de su escritura se encuentra un rasgo central de su vocación profética.

\section{VII}

El poeta cambia, muda de piel, asume otra persona. Es cierto. Pero también el poeta persiste en sí mismo, gira sobre su inmóvil centro, se ratifica. Es claro. El poeta es uno y su sistema, uno también. Por eso, podrá decir con verdad en uno de los versos de su reciente Barcarola (1967):

Yo cambié tantas veces de sol y de arte poética

$$
\text { (O.C., II, 779) }
$$

Pero también es cierto que podrá decir, en uno de los últimos (por ahora) intentos de definir su arte poética:

No he descubierto nada yo,

ya todo estaba descubierto

cuando pasé por este mundo.

Si regreso por estos lados

les pido a los descubridores

que me guarden alguna cosa,

un volcán que no tenga nombre

un madrigal desconocido,

la raíz de un río secreto. 
Fui siempre tan aventurero que nunca tuve una aventura y las cosas que descubrí estaban dentro de mí mismo, de tal modo que defraudé a Juan, a Pedro y a María, porque por más que me esforcé no pude salir de mi casa.

Contemplé con envidia intensa 1a inseminación incesante, el ciclo de los sateloides, la añadidura de los esqueletos, $y$ en la pintura vi pasar tantas maneras fascinantes que apenas me puse a la moda ya aquella moda no existía.

El poema se titula, "Attes poéticas (II)" y pertenece a Fin de mundo (1969), libro en que Neruda hace un recuento de su siglo con una libertad y brío que recuerdan a Estravagario. ${ }^{24}$ Pero el tono zumbón del poema, y la irreverencia del poeta hacia su poesía y hacia los demás, no debe distraer del tema central del poema. Es decir: esa necesidad de afirmar la situación paradójica no sólo del poeta sino del poema, que son (a la vez) redundantes y monótonos, circulares y reiterativos, centrados en sí mismos, en una incesante búsqueda de ese volcán, ese madrigal desconocido, esa raíz de un río secreto. A través de ese poema, Neruda confirma su vocación fatal, su deslumbramiento ante el mundo, su condición de residente en la tierra. Confirma también su don profético.

\section{Emir Rodríguez MonegaL}

\section{Yale University}

24 Pablo Neruda: Fin de mundo (Santiago de Chile, Edición de la Sociedad de Arte Contemporáneo, 1969). 
